Research Article

\title{
Profile of Dermatoses in North and Middle Andaman District of Andaman and Nicobar Islands
}

\author{
${\text { RK Halder', } \text { B Pradeep }^{2}}^{2}$ \\ ${ }^{1}$ Department of Dermatology, G.B. Pant Hospital, Port Blair, India. \\ ${ }^{2}$ Department of Dermatology, SMIMS, Gangtok, Sikkim, India. \\ DOI: https://doi.org/10.24321/2454.8642.201922
}

\section{I $\quad \mathbf{N} \quad \mathbf{F} \quad \mathbf{O}$}

\author{
Corresponding Author: \\ B Pradeep, Department of Dermatology, SMIMS, \\ Gangtok, Sikkim, India. \\ E-mail Id: \\ drprady85@gmail.com \\ Orcid Id: \\ https://orcid.org/0000-0002-6358-0490 \\ How to cite this article: \\ Halder RK, Pradeep B. Profile of Dermatoses \\ in North and Middle Andaman District of \\ Andaman and Nicobar Islands. Rec Adv Path \\ Lab Med 2019; 5(4): 17-22. \\ Date of Submission: 2019-12-03 \\ Date of Acceptance: 2019-12-25
}

\section{$\begin{array}{llllllll}\mathbf{A} & \mathbf{B} & \mathbf{S} & \mathbf{T} & \mathbf{R} & \mathbf{A} & \mathbf{C} & \mathbf{T}\end{array}$}

Background: The study pertaining to prevalence of diseases plays a valuable tool in planning and implementation of health care facilities. The prevalence of skin diseases in North \& Middle Andaman has not been studied earlier.

Methodology: The newly registered out-patients who presented with skin diseases at the $\mathrm{CHC}$ during the period of study, that is, from May 2017 to April 2019 were included in the study. The patients who visited for follow-up were excluded. The patients aged 14 years or below were considered as children (paediatrics).

Result: The incidence of skin diseases among all the general out-patients at $\mathrm{CHC}$, Rangat was found to be $03.956 \%$ in this study. In our study the most predominant skin infection was dermatophyte fungal infection of superficial skin, i.e. $38.05 \%$; followed by Bacterial and viral infections, i.e., $09.76 \%$ and $06.58 \%$ respectively.

Conclusion: We performed this study to highlight the profile of dermatoses in the rural areas of Andaman group of islands which is not yet published in literature till date.

Keywords: Dermatoses, North \& Middle Andaman

\section{Introduction}

North and Middle Andaman is one of the three districts of the Union Territory of Andaman and Nicobar islands. The district was created on $18^{\text {th }}$ August, 2006 by bifurcating erstwhile Andaman district. Mayabunder is the district headquarters. The total area of the district is $3251.85 \mathrm{sq}$. $\mathrm{kms}$. The climate is moist with moderate to heavy rainfall and very high relative humidity. The population of the district was 1,05539 (Census-2011) and Sex ratio of 925 females for every 1000 males. Now the approximate population may be about 1,35000 or more. Majority population of the district is Bengali (> 95\%). The Tamil, Malayali, Telegu and Ranchi community from Chhota Nagpur (Tribals- e.g. Munda, Dungdung, Kerketta, Kispotta, Ekka, etc.) also live in the district.

The socio-economic condition of the people in North and Middle Andaman district is poor. Most of the people in the district are cultivators, labourers, fishermen, small traders, etc. The education facilities are available in the district; but quality of education is very poor. However, the literacy rate is about $86 \%$. 
The pattern of diseases in a community depends on various factors: geography, climate, socio-economic status of the people, educational status, nutrition, food habits, genetic and other habits of the community. In addition, poor hygiene, lack of basic amenities and overcrowding also play significant role in occurrence of diseases. Same is true in case of skin diseases. Thus we performed a study to determine the profile of dermatoses in North and Middle Andaman.

\section{Materials and Methods}

The patients presented exclusively with skin diseases at Community Health Centre, Rangat, Middle Andaman were included in the study. The Community Health Centre, Rangat is situated at the centre of North and Middle Andaman district. The Chief Medical Officer In-charge, at Community Health Centre, Rangat was the only Dermatologist in the department of Health Services and the patients suffering from skin ailments attended to the $\mathrm{CHC}$, Rangat from North and Middle Andaman district. The study period was from May 2017 to April 2019. All the skin patients under study were managed by the dermatologist only. The patient details, diagnosis and treatment provided by the dermatologist were documented. The newly registered out-patients who presented with skin diseases at the $\mathrm{CHC}$ during the period of study, that is, from May 2017 to April 2019 were included in the study. The patients who visited for follow-up were excluded. The patients aged 14 years or below were considered as children (paediatrics). The confirmation of the dermatoses was done by relevant laboratory investigations namely $\mathrm{KOH}, \mathrm{Gram}$ 's stain, Tzanck smear, skin biopsy and serology (HIV, HBsAg, anti-HCV, VDRL).

\section{Result}

Table I.Total general patients versus total Skin patients

\begin{tabular}{|c|c|c|c|}
\hline $\begin{array}{c}\text { Total no of all } \\
\text { out-patients }\end{array}$ & $\begin{array}{c}\text { Total no of } \\
\text { skin out- } \\
\text { patients }\end{array}$ & $\begin{array}{c}\text { Total no of } \\
\text { male skin } \\
\text { patients }\end{array}$ & $\begin{array}{c}\text { Total no of } \\
\text { female skin } \\
\text { patients }\end{array}$ \\
\hline 147871 & 5850 & 2911 & 2937 \\
\hline Percentage (\%) & $03.956 \%$ & $49.760 \%$ & $50.205 \%$ \\
\hline
\end{tabular}

The patients with skin diseases were 3.956\% (reporting for the first time) among all the patients attending out-patient department at $\mathrm{CHC}$, Rangat, and Middle Andaman.

Table 2.Percentage of children amongst the skin patients

\begin{tabular}{|c|c|c|}
\hline $\begin{array}{c}\text { Total no, of Skin } \\
\text { patients }\end{array}$ & $\begin{array}{c}\text { Total no. of } \\
\text { Male children }\end{array}$ & $\begin{array}{c}\text { Total no. of } \\
\text { Female children }\end{array}$ \\
\hline 5850 & 1165 & 1431 \\
\hline Percentage (\%) & $19.914 \%$ & $24.461 \%$ \\
\hline
\end{tabular}

The incidences of skin diseases were almost equal in male and female population. However, the incidence of skin diseases was more in female children than in male children.

Table 3.No. of patients with various skin diseases

\begin{tabular}{|c|c|c|c|}
\hline S. No. & $\begin{array}{l}\text { Type of Skin } \\
\text { Diseases }\end{array}$ & $\begin{array}{c}\text { No. of } \\
\text { patients }\end{array}$ & Percentage \\
\hline 1. & Dermatophytoses & 2228 & $38.05128 \%$ \\
\hline 2. & Pityriasis versicolor & 178 & $03.042 \%$ \\
\hline 3. & Viral Infections & 385 & 06.5812 \\
\hline 4. & Bacterial Infections & 571 & $09.7606 \%$ \\
\hline 5. & Eczemas & 332 & $05.675 \%$ \\
\hline 6. & $\begin{array}{l}\text { Infestations } \\
\text { and Insect bite } \\
\text { reactions }\end{array}$ & 271 & $04.6324 \%$ \\
\hline 7. & $\begin{array}{l}\text { Pigmentary } \\
\text { Dermatoses }\end{array}$ & 502 & $08.581 \%$ \\
\hline 8. & $\begin{array}{c}\text { Sebaceous gland } \\
\text { disorders }\end{array}$ & 803 & $13.726 \%$ \\
\hline 9. & Urticaria & 102 & $01.7435 \%$ \\
\hline 10. & Photodermatoses & 42 & $0.7179 \%$ \\
\hline 11. & Ichthyosis & 22 & $0.3760 \%$ \\
\hline 12. & $\begin{array}{c}\text { Papulosquamous } \\
\text { Dermatoses }\end{array}$ & 138 & $02.3589 \%$ \\
\hline 13. & Hair disorders & 108 & $01.846 \%$ \\
\hline 14. & Bullous Diseases & 08 & $0.13675 \%$ \\
\hline 15. & Others & 160 & $02.735 \%$ \\
\hline Total & & 5850 & \\
\hline
\end{tabular}

Table 4.Details of Fungal Infections

\begin{tabular}{|c|c|c|c|}
\hline $\begin{array}{c}\text { S. } \\
\text { No. }\end{array}$ & $\begin{array}{c}\text { Type of Fungal } \\
\text { infection }\end{array}$ & $\begin{array}{c}\text { Total no. of } \\
\text { patients }\end{array}$ & $\begin{array}{c}\text { Percentage } \\
\text { of patients }\end{array}$ \\
\hline 1. & Tinea corporis & 1099 & $18.786 \%$ \\
\hline 2. & $\begin{array}{c}\text { Tinea corporis et } \\
\text { cruris cruris }\end{array}$ & 600 & $10.256 \%$ \\
\hline 3. & Tinea cruris & 415 & $7.094 \%$ \\
\hline 3. & Tinea incognito & 77 & $01.316 \%$ \\
\hline 4. & Tinea pedis & 12 & $0.205 \%$ \\
\hline 5. & Tinea ungium & 12 & $0.205 \%$ \\
\hline 6. & Tinea manum & 09 & $0.1538 \%$ \\
\hline 7. & Tinea barbie & 03 & $0.05128 \%$ \\
\hline 8. & Tinea capitis & 01 & $0.01709 \%$ \\
\hline 9. & Pityriasis & 178 & $03.0427 \%$ \\
\hline Total & & $\mathbf{2 4 0 6}$ & $\mathbf{4 1 . 1 2 8 2} \%$ \\
\hline
\end{tabular}


Table 5.Details of Bacterial skin infections

\begin{tabular}{|c|c|c|c|}
\hline S. No. & $\begin{array}{c}\text { Type of Bacterial } \\
\text { infection }\end{array}$ & $\begin{array}{c}\text { Total no. of } \\
\text { patients }\end{array}$ & $\begin{array}{c}\text { Percentage } \\
\text { of patients }\end{array}$ \\
\hline 1. & Pyodermas & 492 & $08.4102 \%$ \\
\hline 2. & $\begin{array}{c}\text { Intertriginous } \\
\text { infections and } \\
\text { Intertrigo }\end{array}$ & 41 & $0.7008 \%$ \\
\hline 3. & $\begin{array}{c}\text { Furunculosis \& } \\
\text { Curbuncles }\end{array}$ & 17 & $0.2905 \%$ \\
\hline 4. & $\begin{array}{c}\text { Erysipelas and } \\
\text { Cellulitis }\end{array}$ & 19 & $0.3247 \%$ \\
\hline 5. & Leprosy & 02 & $0.0342 \%$ \\
\hline Total & & $\mathbf{5 7 1}$ & $\mathbf{0 9 . 7 6 0 6 \%}$ \\
\hline
\end{tabular}

Table 6.Details of Viral infections

\begin{tabular}{|c|c|c|c|}
\hline S. No. & $\begin{array}{l}\text { Type of viral } \\
\text { infection }\end{array}$ & $\begin{array}{l}\text { Total no. } \\
\text { of patients }\end{array}$ & $\begin{array}{l}\text { Percentage } \\
\text { of patients }\end{array}$ \\
\hline 1. & $\begin{array}{l}\text { Chichen pox } \\
\text { (varicella) }\end{array}$ & 157 & $02.6837 \%$ \\
\hline 2. & Herpes zoster & 23 & $0.3931 \%$ \\
\hline 3. & Herpes genitalis & 25 & $0.4273 \%$ \\
\hline 4. & $\begin{array}{c}\text { Herpes labialis } \\
\text { and others } \\
\text { (Herpes simplex-I) }\end{array}$ & 13 & $0.2222 \%$ \\
\hline 5. & Measles & 09 & $0.1538 \%$ \\
\hline 6. & Verruca vulgaris & 123 & $02.1025 \%$ \\
\hline 7. & $\begin{array}{l}\text { Molluscum } \\
\text { contagiosum }\end{array}$ & 28 & $0.4786 \%$ \\
\hline 8. & Mumps & 06 & $0.1025 \%$ \\
\hline 9. & $\begin{array}{l}\text { Human Immuno- } \\
\text { defficiency Virus } \\
\text { (HIV) }\end{array}$ & 01 & $0.0171 \%$ \\
\hline Total & & 385 & $06.5812 \%$ \\
\hline
\end{tabular}

The incidence of infective dermatoses was $57.47 \%$. Most common infection was fungal, that is, $41.128 \%$; followed by Bacterial (9.76\%) and Viral infections (6.58\%).

Table 7.Details of Infestations and Insect bite reaction

\begin{tabular}{|c|c|c|c|}
\hline S. No. & $\begin{array}{c}\text { Type of } \\
\text { infestation }\end{array}$ & $\begin{array}{c}\text { Total no. of } \\
\text { patients }\end{array}$ & $\begin{array}{c}\text { Percentage of } \\
\text { patients }\end{array}$ \\
\hline 1. & Scabies & 239 & $04.0854 \%$ \\
\hline 2. & $\begin{array}{c}\text { Pediculosis } \\
\text { capitis }\end{array}$ & 17 & $0.2906 \%$ \\
\hline 3. & $\begin{array}{c}\text { Insect Bite } \\
\text { Reaction }\end{array}$ & 15 & $0.2564 \%$ \\
\hline Total & \multicolumn{271}{|c|}{} & $\mathbf{0 4 . 6 3 2 4 \%}$ \\
\hline
\end{tabular}

The patients with Scabies was highest (04.0854\%), followed by Pediculosis capitis and insect bite reactions.

Table 8.Details of Eczemas

\begin{tabular}{|c|c|c|c|}
\hline S. No. & Type of Eczema & $\begin{array}{c}\text { Total } \\
\text { no. of } \\
\text { patients }\end{array}$ & $\begin{array}{l}\text { Percentage } \\
\text { of patients }\end{array}$ \\
\hline 1. & $\begin{array}{c}\text { Nummular Eczema } \\
\text { and dermatitis }\end{array}$ & 137 & $02.3418 \%$ \\
\hline 2. & $\begin{array}{c}\text { Hand and Finger } \\
\text { eczema }\end{array}$ & 71 & $01.2136 \%$ \\
\hline 3. & Seborrheic dermatitis & 29 & $0.4957 \%$ \\
\hline 4. & $\begin{array}{l}\text { Lichen Simplex } \\
\text { Chronicus (LSC) }\end{array}$ & 29 & $0.4957 \%$ \\
\hline 5. & $\begin{array}{l}\text { Allergic Contact } \\
\text { Dermatitis (ACD) }\end{array}$ & 38 & $0.6495 \%$ \\
\hline 6. & $\begin{array}{l}\text { Irritant Contact } \\
\text { Dermatitis (ICD) }\end{array}$ & 14 & $0.2393 \%$ \\
\hline 7. & Atopic dermatitis & 09 & $0.1538 \%$ \\
\hline 8. & Asteatotic dermatitis & 05 & $0.0854 \%$ \\
\hline Total & & 332 & $05.6752 \%$ \\
\hline
\end{tabular}

Nummular eczema was the predominant eczematous skin diseases (02.3418\%); followed by Hand and Finger eczemas (01.2136\%), Allergic Contact Dermatitis (0.6495\%), Seborrheic Dermatitis (0.4957\%), Lichen Simplex Chronicus $(0.4957 \%)$, Irritant Contact Dermatitis $(0.2393 \%)$, Atopic Dermatitis and Asteatotic Dermatoses $(0.0854 \%)$ in that order.

Table 9.Details of Pigmentation dermatitis

\begin{tabular}{|c|c|c|c|}
\hline $\begin{array}{c}\text { S. } \\
\text { No. }\end{array}$ & $\begin{array}{c}\text { Type of pigmentory } \\
\text { disease }\end{array}$ & $\begin{array}{c}\text { Total no. } \\
\text { of patients }\end{array}$ & $\begin{array}{c}\text { Percentage } \\
\text { of patients }\end{array}$ \\
\hline 1. & Melasma & 280 & $04.786 \%$ \\
\hline 2. & Vitiligo & 189 & $03.231 \%$ \\
\hline 3. & Freckles & 17 & $0.290 \%$ \\
\hline 4. & $\begin{array}{c}\text { Post-inflammatory } \\
\text { hyperpigmentation }\end{array}$ & 14 & $0.2393 \%$ \\
\hline 5. & $\begin{array}{c}\text { Post-inflammatory } \\
\text { hypopigmentation }\end{array}$ & 02 & $0.0341 \%$ \\
\hline Total & & $\mathbf{5 0 2}$ & $\mathbf{0 8 . 5 8 1 \%}$ \\
\hline
\end{tabular}

Table 10.Details of disorders of Sebaceous gland

\begin{tabular}{|c|c|c|c|}
\hline S. No. & Type of disease & $\begin{array}{c}\text { Total no. of } \\
\text { patients }\end{array}$ & $\begin{array}{c}\text { Percentage } \\
\text { of patients }\end{array}$ \\
\hline 1. & Acne vulgaris & 801 & $13.692 \%$ \\
\hline 2. & Rosacea & 02 & $0.03418 \%$ \\
\hline Total & & $\mathbf{8 0 3}$ & $\mathbf{1 3 . 7 2 6 4 \%}$ \\
\hline
\end{tabular}


Table I I.Details of Urticaria

\begin{tabular}{|c|c|c|c|}
\hline S. No. & Type of disease & $\begin{array}{c}\text { Total no. of } \\
\text { patients }\end{array}$ & $\begin{array}{c}\text { Percentage } \\
\text { of patients }\end{array}$ \\
\hline 1. & Chronic Urticaria & 58 & $0.99145 \%$ \\
\hline 2. & $\begin{array}{c}\text { Dermographism, } \\
\text { acute popular } \\
\text { urticari, etc. }\end{array}$ & 44 & $0.7521 \%$ \\
\hline Total & & 102 & $\mathbf{1 . 7 4 3 5 \%}$ \\
\hline
\end{tabular}

Table 12.Details of Photodermatitis

\begin{tabular}{|c|c|c|c|}
\hline S. No. & Type of disease & $\begin{array}{c}\text { Total no. } \\
\text { of patients }\end{array}$ & $\begin{array}{c}\text { Percentage } \\
\text { of patients }\end{array}$ \\
\hline 1. & PMLE & 27 & $0.4615 \%$ \\
\hline 2. & $\begin{array}{c}\text { Acute Sun-burn } \\
\text { and tanning }\end{array}$ & 09 & $0.1538 \%$ \\
\hline 3. & Solar Keratosis & 06 & $0.10256 \%$ \\
\hline Total & & $\mathbf{4 2}$ & $\mathbf{1 . 7 4 3 5 \%}$ \\
\hline
\end{tabular}

Table I3.Details of Ichthyosis and other disorders

\begin{tabular}{|c|c|c|c|}
\hline S. No. & $\begin{array}{c}\text { Type of pigmentory } \\
\text { disease }\end{array}$ & $\begin{array}{c}\text { Total no. } \\
\text { of patient }\end{array}$ & $\begin{array}{c}\text { Percentage } \\
\text { of patients }\end{array}$ \\
\hline 1. & Ichthyosis vulgaris & 07 & $0.1196 \%$ \\
\hline 2. & Lamellar Ichthyosis & 03 & $0.05128 \%$ \\
\hline 3. & Acanthosis nigricans & 11 & $0.1880 \%$ \\
\hline 4. & Darier's Disease & 01 & $0.01709 \%$ \\
\hline Total & & $\mathbf{2 2}$ & $\mathbf{0 . 3 7 6 0 \%}$ \\
\hline
\end{tabular}

Table I4.Details of Papulosquamous disorders

\begin{tabular}{|c|c|c|c|}
\hline S. No. & Type of disorder & $\begin{array}{c}\text { Total No. } \\
\text { of patients }\end{array}$ & $\begin{array}{c}\text { Percentage } \\
\text { of patients }\end{array}$ \\
\hline 1. & Psoriasis vulgaris & 50 & $0.8547 \%$ \\
\hline 2. & $\begin{array}{c}\text { Palmo-planter } \\
\text { Keratoderma }\end{array}$ & 62 & $01.0598 \%$ \\
\hline 3. & Parapsoriasis & 13 & $0.2222 \%$ \\
\hline 4. & Lichen planus & 13 & $0.2222 \%$ \\
\hline Total & & $\mathbf{1 3 8}$ & $\mathbf{0 2 . 5 8 1 2 \%}$ \\
\hline
\end{tabular}

Table I5.Details of Bullous disorders

\begin{tabular}{|c|c|c|c|}
\hline $\begin{array}{l}\text { S. } \\
\text { No. }\end{array}$ & $\begin{array}{c}\text { Type of Bullous } \\
\text { disease }\end{array}$ & $\begin{array}{l}\text { Total no. } \\
\text { of patient }\end{array}$ & $\begin{array}{l}\text { Percentage } \\
\text { of patients }\end{array}$ \\
\hline 1. & Pemphigous vulgaris & 02 & $0.03418 \%$ \\
\hline 2. & Bullous pemphyygoid & 03 & $0.05128 \%$ \\
\hline 3. & $\begin{array}{c}\text { Chronic Bullous } \\
\text { Disease of Childhood } \\
\text { (CBDC) }\end{array}$ & 03 & $0.05128 \%$ \\
\hline Total & & 08 & $0.13675 \%$ \\
\hline
\end{tabular}

Incidence of Melasma was highest among the patients with Pigmentation skin diseases; followed by Vitiligo and other pigmentation skin diseases.

Table I6.Details of Hair disorders

\begin{tabular}{|c|c|c|c|}
\hline S. No. & $\begin{array}{c}\text { Type of Hair } \\
\text { disease }\end{array}$ & $\begin{array}{c}\text { Total no. } \\
\text { of patients }\end{array}$ & $\begin{array}{c}\text { Percentage } \\
\text { of patients }\end{array}$ \\
\hline 1. & $\begin{array}{c}\text { Androgenic } \\
\text { Alopecia (MPA) }\end{array}$ & 39 & $0.6666 \%$ \\
\hline 2. & Alopecia areata & 42 & $0.7179 \%$ \\
\hline 3. & Alopecia totalis & 03 & $0.05128 \%$ \\
\hline 4. & $\begin{array}{c}\text { Other hair } \\
\text { disorders }\end{array}$ & 24 & $0.41025 \%$ \\
\hline Total & \multicolumn{1}{|c|}{} & $\mathbf{1 0 8}$ & $\mathbf{0 1 . 8 4 6 1 \%}$ \\
\hline
\end{tabular}

The second most common skin disease in our study was Acne vulgaris (13.692\%), followed by Pigmentation dermatoses (08.581\%), Eczema (05.675\%), Scabies (04.0854\%), Papulosquamous dermatoses (02.3589\%), Hair disorder (01.846\%), Urticaria (01.7435\%), Photodermatitis $(0.7179 \%)$, Ichthyosis $(0.3760 \%)$ and Bullous Diseases $(0.13675 \%)$ in the order of decreasing frequency.

Table I7.Miscellaneous skin diseases

\begin{tabular}{|c|c|c|c|}
\hline $\begin{array}{l}\text { S. } \\
\text { No. }\end{array}$ & Skin diseases & $\begin{array}{l}\text { Total no. } \\
\text { of patients }\end{array}$ & $\begin{array}{l}\text { Percentage } \\
\text { of patients }\end{array}$ \\
\hline 1. & Wounds and ulcers & 38 & $0.6495 \%$ \\
\hline 2. & Ingrowing toe nails & 13 & $0.2222 \%$ \\
\hline 3. & $\begin{array}{c}\text { Schamburg's } \\
\text { disease }\end{array}$ & 11 & $0.18803 \%$ \\
\hline 4. & Aphthus ulcers & 09 & $0.1538 \%$ \\
\hline 5. & $\begin{array}{c}\text { Fibrosis of oral } \\
\text { mucosa }\end{array}$ & 08 & $0.1367 \%$ \\
\hline 6. & $\begin{array}{l}\text { Non-specific } \\
\text { pruritis }\end{array}$ & 05 & $0.08547 \%$ \\
\hline 7. & Milaria & 02 & $0.03418 \%$ \\
\hline 8. & $\begin{array}{c}\text { Keloid and } \\
\text { hypertrophic scars }\end{array}$ & 04 & $0.06837 \%$ \\
\hline 8. & Senile purpura & 04 & $0.06837 \%$ \\
\hline 9. & Senile keratosis & 06 & $0.10256 \%$ \\
\hline 10. & $\begin{array}{c}\text { Henoch Schonlein } \\
\text { purpura }\end{array}$ & 03 & $0.05128 \%$ \\
\hline 11. & Neurofibroma & 04 & $0.06837 \%$ \\
\hline 12. & Epidermal Naevus & 04 & $0.06837 \%$ \\
\hline 13. & $\begin{array}{l}\text { Chronic pastular } \\
\text { folliculitis }\end{array}$ & 03 & $0.05128 \%$ \\
\hline 14. & $\begin{array}{c}\text { Acrochordon (skin } \\
\text { tag) }\end{array}$ & 06 & $0.10256 \%$ \\
\hline
\end{tabular}




\begin{tabular}{|c|c|c|c|}
\hline 15. & Epidermoid cyst & 10 & $0.1709 \%$ \\
\hline 16. & Lipoma & 03 & $0.05128 \%$ \\
\hline 17 & Erythroderma & 01 & $0.0171 \%$ \\
\hline 18 & SLE & 01 & $0.0171 \%$ \\
\hline 19 & $\begin{array}{c}\text { Progressive } \\
\text { Systemic Sclerosis } \\
\text { (PSS) }\end{array}$ & 02 & $0.03418 \%$ \\
\hline 20. & $\begin{array}{c}\text { Hyperhidrosis of } \\
\text { palms and soles }\end{array}$ & 02 & $0.03418 \%$ \\
\hline 21. & Poikiloderma & 03 & $0.05128 \%$ \\
\hline 22. & $\begin{array}{c}\text { Toxic Epidermal } \\
\text { Necrolysis }\end{array}$ & 01 & $0.0171 \%$ \\
\hline 23. & Perioral dermatitis & 04 & $0.06837 \%$ \\
\hline Total & \multicolumn{2}{|c|}{$0.5128 \%$} \\
\hline
\end{tabular}

Wounds and Ulcers (superficial and sub-cutaneous) were the maximum cases $(0.6495 \%)$ in the miscellaneous group with 38 cases out of 147 patients

\section{Discussion}

Our study outlines the spectrum of skin diseases that presented to the Community Health Centre, Rangat, situated almost in the centre of the district, during the period from May, 2017 to April, 2019. This is a unique study of skin diseases in the rural areas of remote Andaman Islands. No published work on skin diseases in the rural areas of North and Middle Andaman is available in any indexed journal. The prevalence of skin diseases in the general population varied from $07.86 \%$ to $11.16 \%$ in various studies. ${ }^{1,2}$ In our study only the newly registered skin patients were considered. Therefore, only the incidence of the skin diseases during the period of study was known. The incidence of the patients with newly diagnosed skin diseases among all the general out-patients at CHC, Rangat was found to be $03.956 \%$ in the study. Skin patients comprised $4.5 \%$ of all the cases in another study conducted in unreached Hilly Areas of North India. ${ }^{3}$ These results of the study corroborate with those of our study. The results of the present study showed that the incidences of skin diseases were almost equal in male and female population. However, the incidence of skin diseases was more in female children than in male children.

The results of the present study showed that majority of the newly diagnosed skin diseases were infective dermatoses (57.47\%), the disorder of skin appendages, pigmentation skin diseases, eczemas, infestations and other disorders of skin. Among the infections of the skin the most common was fungal infections. Similarly, another study conducted in unreached Hilly Areas of North India found infective dermatoses to be the most common diagnosis (32.6\%), followed by the disorders of skin appendages (19.8\%),
Dermatitis and Eczema (18.8\%), etc. ${ }^{4}$ A study was conducted on a small group of Nicobarie tribes numbering 375 at a community medical camp held at Kamorta of Nicobar group of islands revealed that the incidence of infective dermatoses was the highest, i.e. $46.90 \%$ in the study. ${ }^{4}$

Studies conducted in Bundelkhand showed the prevalence of infections to be $53.18 \%{ }^{5} 41.9 \%$ in the North Eastern state of Assam, ${ }^{6} 42.68 \%$ in Bantwal which is a coastal area in Karnataka, ${ }^{7} 41.2 \%$ in Pune, ${ }^{8} 39.54 \%$ in Kolkata, ${ }^{9}$ $34.1 \%$ in the Kashmir valley, ${ }^{10} 32.6 \%$ in Unreached Hilly Area of Uttarakhand. ${ }^{3}$ The highest incidences of infections amongst the skin diseases at Kamorta, Assam, coastal area of Karnataka and in Pune could be attributed to the similar climatic conditions of high humidity and moderately high temperatures in all these regions. Moderate to high temperature, high humidity, the poor socio-economic condition of the people, lack of awareness and quality education could be attributed to high incidence of infection in the rural populace of North and Middle Andaman district.

In our study the most predominant skin infection was dermatophyte fungal infection of superficial skin, i.e. $38.05 \%$; followed by Bacterial and viral infections, i.e., $09.76 \%$ and $06.58 \%$ respectively.

\section{Conclusion}

We performed this study to highlight the profile of dermatoses in the rural areas of Andaman group of islands which is not yet published in literature till date.

\section{Conflict of Interest: None \\ References}

1. Grover S, Ranyal RK, Bedi MK. A cross section of skin diseases in rural Allahabad. Indian J Dermatol 2008; 53(4): 179-181. Available from: http://www.e-ijd.org/ article.asp?issn $=0019-5154$; year $=2008$; volume $=53$;iss ue $=4$; spage $=179$; epage $=181$; aulast $=$ Grover [PubMed/ Google Scholar].

2. Rao GS, Kumar SS, Sandhya. Pattern of skin diseases in an Indian village. Indian J Med Sci 2003; 57: 108110. Available from: https://europepmc.org/article/ med/14514260 [PubMed/ Google Scholar].

3. Dimri D, Reddy B, Kumar Singh A. Profile of skin disorders in unreached hilly areas of North India. Dermatology research and practice 2016; Article ID 8608534: 6. Available from: https://www.hindawi.com/journals/ drp/2016/8608534/ [PubMed/ Google Scholar].

4. Subramaniyan R. Pattern of dermatoses among Nicobarese in a community health camp at Nancowry, Andaman and Nicobar Islands. Indian J Dermatol 2016; 61(2): 187-189. Available from: http://www.e-ijd.org/ article.asp?issn=0019-5154; year $=2016$; volume $=61 ; i$ ssue $=2$; spage $=187$; epage $=189$; aulast $=$ Subramaniyan [PubMed/ Google Scholar]. 
5. Dayal SG, Gupta GD. A cross section of skin diseases in Bundelkhand region, UP. Indian J DermatolVenereol Leprol 1977; 43(5): 258-261. Available from: http:// www.ijdvl.com/temp/ijdvl435258-2655271_072232. pdf [PubMed/ Google Scholar].

6. Jaiswal AK. Ecologic perspective of dermatologic problems in North Eastern India. Indian I Dermatol Venereol Leprol 2002; 68(4): 206-207. Available from: http://www.ijdvl.com/article.asp?issn=0378-6323;yea $r=2002$; volume $=68$;issue $=4$; spage $=206$; epage $=207$; au last=Jaiswal [PubMed/ Google Scholar].

7. Kuruvilla M, Sridar KS, Kumar P, Rao G. Pattern of skin diseases in Bantwal Taluq, Dakshina Kannada. Indian J DermatolVenereol Leprol 2000; 66: 247-248. Available from: http://www.ijdvl.com/article.asp?issn=03786323; year $=2000$; volume $=66$; issue $=5$; spage $=247$; epa ge=248; aulast=Kuruvilla [PubMed/ Google Scholar].

8. Sayal SK, Das AL, Gupta CM. Pattern of skin diseases among civil population and armed forces personnel at Pune. Indian I Dermatol Venereol Leprol 1997; 63(1): 29-32. Available from: http://www.ijdvl.com/article. asp?issn $=0378-6323$; year $=1997$; volume $=63$; issue $=1$ ; spage $=29$; epage $=32$; aulast $=$ Sayal $[\mathrm{PubMed} /$ Google Scholar].

9. C Kar, S Das, A Roy. Pattern of skin diseases in a tertiary institution in Kolkata. Indian J Dermatol 2014; 59(2): 209. Available from: http://www.e-ijd.org/article. asp?issn=0019-5154; year $=2014$; volume $=59$;issue $=2$; spage $=209$; epage $=209$; aulast $=$ Kar $[$ PubMed $/$ Google Scholar].

10. Hassan I, Anwar P, Bilquis S, Nabi S, Rasool F, Munshi I. Comparison of dermatoses seen in community health camps and a tertiary care centre in Kashmir. Indian J Dermatol Venereol Leprol 2014; 80(3): 214220. Available from: http://www.ijdvl.com/article. asp?issn=0378-6323; year $=2014$; volume $=80$; issue $=$ 3 ; ppage $=214$; epage $=220$; aulast $=$ Hassan $[$ PubMed/ Google Scholar]. 